\title{
Human Resource Management in Turkey
}

Teoman Alemdar

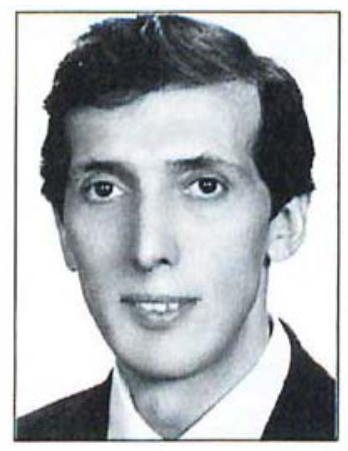

Teoman Alemdar is the chairman of the Tourism and Hotel Management Department and the Tourism and Hotel Services Department in the School of Tourisn and Hotel Management, Bilkent Lniversity. He oversaze the construction phase and grand opening of a fivestar hotel in Alanya, a city in the Antalya province of Turkey, and managed the hotel for two years before joining Bilkent University in 1991. His other hospitality experience includes jobs with the Maçka Hotel and Etap Istanbul in Istanbul and, in the United States, jobs woith Holiday Inn, ITT Sheraton, and Don Cesar Beach Resort. He is a graduate of Florida International Lniversity's School of Hospitality Management.

\footnotetext{
“T
}

The Gateway betweEn Europe And Asta"; "the crossroads of civilization"; these and similar phrases are typically applied to Turkey, and no wonder. Turkey is located where three continents making up the Old World-Asia, Africa, and Europe-come closest to each other: The Asia Minor.

Turkey has also been called "the cradle of civilization." Çatalhöyük, a Neolithic city thought to be one of the world's first, dates back to 6,500 B.C. From the days of Çatalhöyük up to the present, Turkey boasts a rich culture that has made a lasting impression on modern civilization. Hattis, Hittites, Phrygians, Urartians, Lycians, Lydians, Ionians, Persians, Macedonians, Romans, Byzantines, Seljuks, and Ottomans have all made important contributions to Turkish history.

Turkey has a total area of 780,580 square kilometers. The main area of Turkey, Anatolia, is in Asia between the Mediterranean and Black Seas (see Exhibit 1). Thrace, the European region of the country, lies to the northwest of the Sea of Marmara and makes up just three percent of the country's territory. The country is bordered in the east by Georgia, Armenia, and Iran, and in the south by Iraq, Syria, and the Mediterranean Sea. The Aegean Sea, Greece, and Bulgaria are to the west, and the Black Sea forms the northern border. Almost surrounded by seas, Turkey's coastline is more than 8,333 kilometers long. İstanbul is the largest city in Turkey; Ankara is the capital. 


\section{Exhibit 1 Map of Turkey}

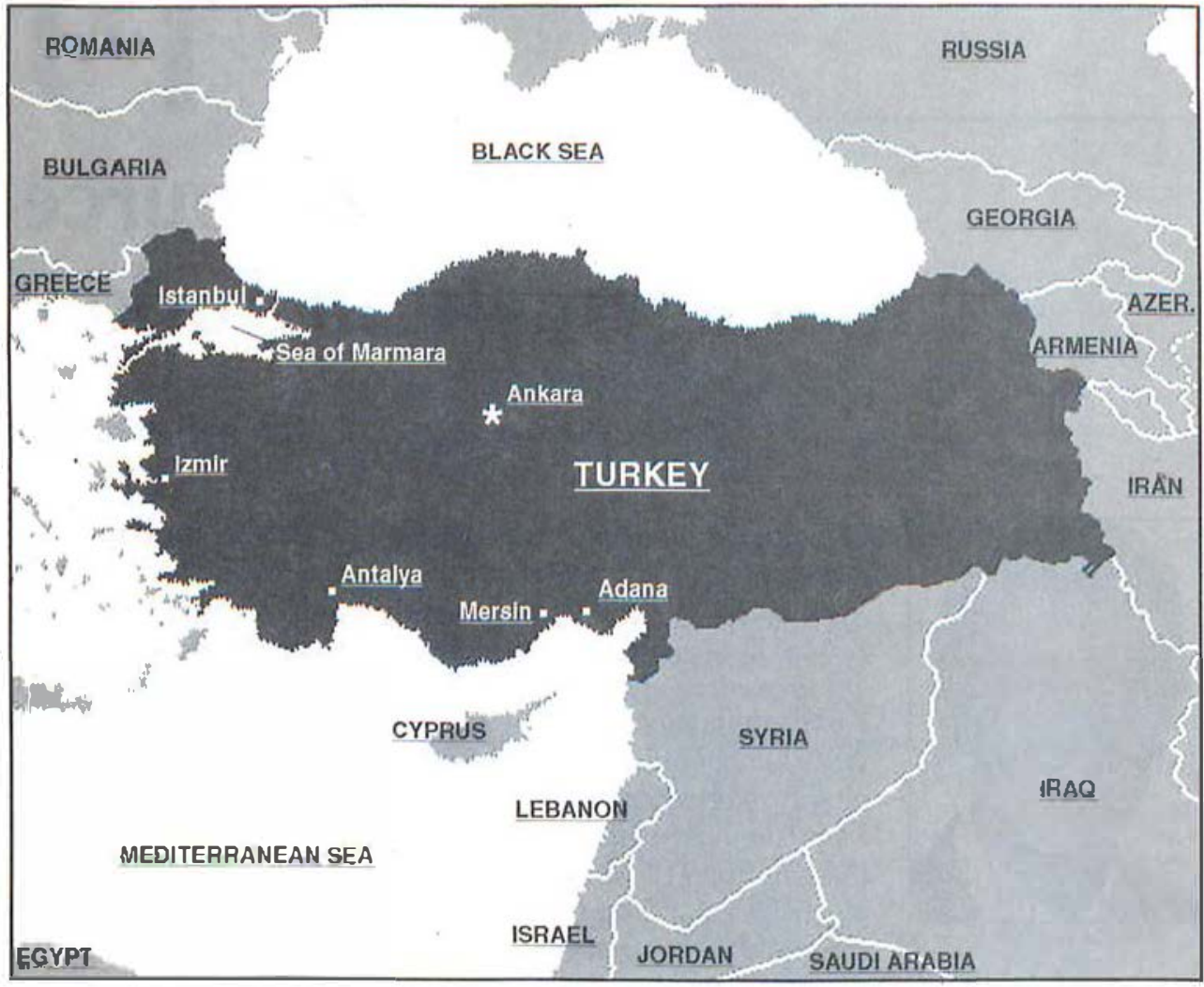

Turkey is a paradise of sun, sea, mountains, and lakes that offers tourists a complete change from the routine of everyday life. It enjoys a variety of climates, from the temperate climate of the Black Sea region, to the continental climate of the interior, to the Mediterranean climate of the Aegean and Mediterranean coastal regions.

In this chapter, we will take a brief look at Turkey's economy in general and the Turkish tourism industry in particular. We will explore human resource issues in Turkey, including demographics, cultural influences on the Turkish work force, and the status of working women in Turkey. Next we will discuss expatriate managers, in Turkish companies as well as international companies, and identify the biggest difference between Turkish and international corporate cultures. The chapter concludes with a glimpse of near-future trends for the country.

\section{Turkey: A Brief Overview}

Turkey has been a secular and democratic republic since 1923. The Republic of Turkey is based on a pluralistic and parliamentary system, where human rights are protected by law. The $\mathbf{5 5 0}$-member National Assembly is elected by popular vote. 
The nation is governed by the Council of Ministers, which is headed by the prime minister, who represents the majority party or coalition in the assembly; when necessary, the prime minister consults with Turkey's president. The president is chosen by the assembly and serves a seven-year term. Assembly members serve five-year terms.

Turkey is a founding member of the United Nations, the Organization for Economic Co-Operation and Development, and the Black Sea Economic Cooperation Organization, and is a member of:

- $\quad$ NATO (North Atlantic Treaty Organization)

- GATT (General Agreement on Tariffs and Trade)

- WTO (World Trade Organization)

- IMF (International Monetary Fund)

- UNESCO (United Nations Educational, Scientific and Cultural Organization)

- FAO (Food and Agriculture Organization of the United Nations)

- INTERPOL (International Criminal Police Organization)

- IDB (Islamic Development Bank)

- The European Council

- The European Parliament

Turkey is also an associate member of the European Union.

Although 98 percent of its population is Muslim, Turkey also has citizens who practice the Jewish, Catholic, Orthodox, Protestant, and Gregorian faiths. State and religious af fairs are considered two separate domains. People enjoy the right and freedom to worship according to the faith of their choice.

The political structure of Turkey is complex, with several political parties on the right and left wings and liberals in between. The political parties and their aims and ambitions are considered reasonable by a majority of the public, with one exception; a religion-based right-wing party that seeks to rebuild the Turkish Republic under Islamic rules. The supporters of this party have also invested in tourism, building and operating a few hotels where Islamic rules are carried out, such as no alcoholic drinks on the premises and separate beaches for men and women.

\section{The Turkish Economy}

Turkey has achieved a remarkable transformation from an inward-looking economy based on import substitution-that is, creating Turkish substitutes for imported essentials-to an outward-looking economy that is integrated with the rest of the world in almost all sectors.

The government has a great deal of influence over the Turkish economy and owns several important industries, such as the railroad industry (run by the Turkish Republic State Railways). The government also operates four national radio networks and five television channels. Five-Year Development Plans are prepared by the State Planning Organization and are put in effect when a bill is passed by the 
National Assembly. These FiveYear Development Plans drive the public sector and provide guidelines for the private sector.

Turkey is among the world's leaders in the production of chromium ore, extracting 1.7 million metric tons in 1996.' Principal exports are textiles, iron and steel, dried fruits, leather garments, tobacco, and petroleum products. Chief imports are machinery, crude petroleum, transportation vehicles, and chemical products. The government's liberalization of foreign trade policies played an important role in transforming Turkey from an agricultural commodities exporter, trading mainly with its neighbors, to a worldwide trader, exporting mainly industrial goods. The volume of trade, exports plus imports, rose from $\$ 11$ billion in 1980-15 percent of the Gross National Product (GNP) - to $\$ 68$ billion in 1996 (40 percent of GNP). Turkey has become one of the seven countries in the Organization for Economic Co-Operation and Development that has the least number of restrictions on capital account transactions.

Similar to most other countries in the world, the economic policies of all Turkish governments have been based on a mixed-economy system, but it is natural that over the years successive governments have adopted varying economic policies, due to the changing economic conditions at home and in the rest of the world. H lowever, most Turkish administrations have shared a basic aim: increase the market share of Turkey's private sector and reduce the public sector's commercial ventures in the Turkish economy.

\section{Tourism in Turkey}

Turkey has experienced major improvements in its tourism industry, in part due to efforts by the Turkish government. Turkey's Ministry of Tourism was established by Law No. 265 in 1963. This was followed by the Travel Agencies and Union of Travel Agencies Law No. 1618, put in effect on September 29, 1972. The Tourism Encouragement Frame Decree was passed by the National Assembly in 1980. Finally, the Tourism Encouragement Law No. 2634 was passed on March 12, 1982.

However, prior to 1985, tourism growth stayed below expectations despite these legal changes. In 1985, the government benchmarked other leading countries' tourism performances and identified major deficiencies with Turkey's tourism effort. The government then introduced monetary incentives such as grants and allowances for tourism businesses, following the example of countries that had implemented similar incentives. Turkey has enjoyed steady progress and a great deal of achievement in the tourism industry since these and other tourismfriendly measures were undertaken. In fact, Turkey's tremendous tourism success has drawn notice in the international arena, because so many countries are interested in the positive economic impact that can be created by foreign visitors. International tourism is now a big business in Turkey; it generated approximately $\$ 7$ billion in forcign travel receipts in 1997, which is almost 26 percent of Turkey's Foreign Exchange and Export revenues.

The basic concept of 1982's Tourism Encouragement Law was to build up a new, modern tourist industry with an emphasis on the lodging sector. Under this law, hospitality properties that conform to the terms and regulations of the law are given licenses by the Turkish government. Properties that do not meet these 
standards remain under the control of local authorities, such as municipalities. Currently, Turkey has 3,319 hotels and holiday villages licensed by the Ministry of Tourism, with a 563,340bed capacity; 7,975 hotels are under the control of municipalities, with a total capacity of 344,551 beds. The area with the greatest density of lodging properties lies from Balikesir province, throughout the coastal strip of the Aegean and Mediterranean shores, to the Mersin province. The Antalya province has been considered the capital of Turkey's tourism industry. The Kemer and Belek regions are the prime resort development locations in Antalya, with properly designed, environmentally sound, and highly popular resorts. There is a 140,000-bed capacity in Antalya province alone.

Istanbul, a world city of fascinating museums, churches, palaces, mosques, bazaars, and sights of inexhaustible natural beauty, is considered the pearl of Turkey's tourism industry. Most of the national and international five-star deluxe hotels, the majority of Turkey's travel agencies, and the headquarters of many national and private airline companies are found in Istanbul.

In order to ease tourist pressure on the coastal areas of the country, Turkey's tourism industry has adapted diversification policies. Mountaineering, scuba diving, hiking, golfing, horseback riding, winter holidays and sports, cultural and other tours, spas, meetings and conferences, and incentive travel have been promoted in order to better utilize the wide range of Turkey's diverse resources.

In 1998, a total of 9,752,697 foreign tourists visited Turkey (see Exhibit 2), mostly for holiday purposes ( 56 percent), followed by cultural reasons ( 11 percent), business ( 6 percent), and shopping ( 6 percent). Turkey enjoyed tremendous prog ress in the 1990s in tourism, but, for any country in the world, it is not realistic to expect tourism trends to increase all the time, because competition in the international tourism market is intense. Economic crises and social unrest in Asia, devaluation of currencies, reduction of value-added taxes and airport taxes in competitor countries, the revitalization of the Croatian and Egyptian hospitality industries, the financial crisis in Russia, uncertainties concerning Euromoney, and acts of terrorism-all have affected Turkey's tourism industry in recent years. From January to October of 1998, total visitor arrivals to Turkey decreased 1.2 percent over the same period in 1997. Though it was a minor drop, the government is considering adopting measures to head of $f$ further declines.

\section{Human Resource Issues}

In the following sections, we will discuss several human resource issues:

- Labor demographics

- Labor market issues

- Cultural factors

- Recruitment and selection practices

- Training and development practices

- Performance evaluation practices

- Working women in Turkey 
Exhibit 2 Foreign Arrivals by Nationalities

\begin{tabular}{|lr|}
\hline Nationality & \multicolumn{1}{c|}{1998} \\
Germany & $2,233,740$ \\
CIS & $1,311,357$ \\
U.K. & 996,512 \\
Romania & 505,766 \\
USA & 439,885 \\
France & 436,932 \\
Netherlands & 328,002 \\
Iran & 304,924 \\
Italy & 259,483 \\
Bulgaria & 244,741 \\
Israel & 238,298 \\
Austria & 235,120 \\
Sweden & 156,116 \\
Others & $2,061,821$ \\
Total & $9,752,697$ \\
\hline
\end{tabular}

Exhibit 3 Profile of Tourism Personnel

\begin{tabular}{|lccc|}
\hline Sex & Accommodation & Restaurants & Travel Agencies \\
Male & $81 \%$ & $93 \%$ & $64 \%$ \\
Female & $19 \%$ & $7 \%$ & $36 \%$ \\
Total & $100 \%$ & $100 \%$ & $100 \%$ \\
\hline
\end{tabular}

Source: 1993 Manpower Survey of the Tourism Industry by the Ministry of Tourism and the International labour Organization.

\section{Labor Demographics and Labor Market Issues}

The population of Turkey is estimated to be around $65,311,000$ by Turkey's State Institute of Statistics (SIS). ${ }^{2}$ According to the Women's Indicators and Statistics of SIS, women make up almost half of the population (49.5 percent). However, this percentage does not hold true in the hospitality workplace. The staffs of hotels, restaurants, and travel agencies are still dominated by men (see Exhibit 3).

The most noteworthy fact in the Percentage of Turkey's Population by Age Group statistics is that 55.6 percent of the population is under the age of 25 (see Exhibit 4), making Turkey a country dominated by the young. Having such a large 


\section{Exhibit 4 Percentage of Turkey's Population by Age Croup}

\begin{tabular}{|lc|}
\hline Age Group & Percentage \\
$0-24$ & 55.6 \\
$25-44$ & 27.0 \\
$45-64$ & 13.5 \\
$65+$ & 3.8 \\
Unknown & .10 \\
Total & 100.00 \\
\hline
\end{tabular}

Source: State Institute of Statistics, 1990.

percentage of the country's population in this age group puts a tremendous strain on Turkey's educational system. It will also be difficult to find jobs for all of these people when their schooling is finished.

Turkish Labor Law No. 1475 was put in effect on August 25, 1971. It was designed to secure the working conditions of all employees, as well as give employers legal recourse when worker abuses take place. The law dictates that an employee's normal working day is 7.5 hours. Article No. 35 of the law sets an employee's daily overtime at a maximum of three hours, and an employee cannot lawfully have more than 90 overtime days in a year. Overtime pay is one and a half times the regular hourly wage; all work on public holidays is considered overtime. Despite Labor Law No. 1475, many hotel companies-most of them in the resort cities along Turkey's Aegean and Mediterranean coasts-force employees to work ten to twelve hours per day, six days a week, with no overtime pay.

All employees have the right to join a union but they don't have to. Turkish employers must have a good reason to fire an employee; if they do not have a good reason and they fire an employee anyway, they must, by law, compensate the employee by paying him or her what amounts to a "separation fee." Because of these and other worker-friendly policies passed by the government in the past decade, many labor organizations have declined almost to the point of extinction.

There are three social security systems for Turkey's working citizens: Emekli Sandiḡi (ES) - the social security system for government officials; Sosyal Sigortalar Kurumu (SSK) - the social security system for public- and private-sector employees; and Bag-Kur (BK)-the social security system for small business owners. These systems are facing the prospect of reorganization and possible consolidation by the Turkish government under a new umbrella institution. All employers are obliged to register all of their employees with the SSK and to pay part of the employer's social-security contribution fee in the names of their employees. The SSK, which covers almost all employees working in the tourism industry, has 5,500,000 registered employees. Based on the 1995 census, the SIS surveys show that 460,000 individuals are directly employed by the hotel and restaurant industries. Today, almost 2.5 million people in Turkey make their living directly or indirectly, or earn at least a part of their income, from the tourism industry: 
Turkey's tourism industry is heavily dependent on Turkish employees who can properly speak such foreign languages as English, German, French, Italian, Spanish, Russian, and Arabic. The most crucial requirement for a worker to be employed by a tourist company in Turkey is his ability to communicate in at least one of the languages spoken by that company's major tourist groups. A person who speaks German fluently has a better chance to get a job offer from a resort property on Turkey's Mediterranean coast than a new Vocational Schisol of Tourism graduate who has a basic knowledge of the hotel and restaurant business but can't speak German. English is mostly preferred in large metropolitan cities where international hotel companies are located, such as İstanbul, Ankara, and izmir, and on the Aegean coast of Turkey, where some of the resort hotels and holiday villages are linked to British tour operators. The tendency of Turkish hospitality companies is to pass over university graduates who only speak Turkish to recruit less educated people who are fluent in a foreign language.

Because of the seasonal nature of most resort jobs, university graduates also tend to be passed over by hotel companies operating in the Aegean and Mediterranean resort areas. For these resort properties, the tourist season lasts around seven to eight months, starting in the middle of March and going until the beginning of November. Therefore, these properties employ seasonal staff and only keep necessary personnel, such as top management staff and security and engineering department personnel, during the winter season when the resorts are closed down. Even though the top managers of these resorts prefer to work with graduates of tourism and hotel management schools, they hesitate to recruit them because they can only offer seasonal jobs with no job security and low salaries.

Foreign tour operators offer low package tour rates to their clients traveling to Turkey, which forces hotel companies in Turkey to employ mostly low-cost personnel in order to make some profit at the end of the season. Market factors weaken the bargaining power of individual employees to increase their wages. Unions are very much concerned with these problems and attempt to establish themselves in such an environment. Although it would seem that hotels and resorts in the Aegean and Mediterranean regions would be the best places for unions to increase their numbers and therefore augment their power, two of the leading labor confederations-Türk-Iss' TOLEYIS (which began in 1977), with 37,000 members, and DiSK's OLEYIS (started in 1947), with 25,000 members-represent employees working in metropolitan destinations such as İstanbul, Ankara, and İzmir.

In many cases, educational preparation in the tourism field is necessary to enable personnel to perform the duties required of them. However; many hotels and restaurants find themselves obliged to fill entry-level positions with individuals who barely meet the job specifications, and pay them the minimum wage, which is currently the equivalent of $\$ 200$ per month (including taxes). This kind of hiring leads to high turnover rates and quality problems regarding service levelsmajor headaches for hospitality human resource departments. With high turnover, human resource departments struggle to train employees and improve their job performance, only to lose them and have to start over with newly hired employees.

Currently, Turkey has 48 universities offering 12 bachelor's and 36 associate programs leading to degrees in the field of tourism and hotel management. As you 
Exhibit 5 Distribution of Personnel According to Level of Formal Education

\begin{tabular}{|lccc|}
\hline $\begin{array}{l}\text { Level of } \\
\text { Education }\end{array}$ & Accommodation & Restaurants & $\begin{array}{c}\text { Travel } \\
\text { Agencies }\end{array}$ \\
None & $1 \%$ & $2 \%$ & $1 \%$ \\
Primary & $41 \%$ & $49 \%$ & $10 \%$ \\
Secondary & $16 \%$ & $22 \%$ & $6 \%$ \\
High School & $31 \%$ & $22 \%$ & $46 \%$ \\
University & $11 \%$ & $5 \%$ & $37 \%$ \\
Total & $100 \%$ & $100 \%$ & $100 \%$ \\
\hline
\end{tabular}

Source: [993 Manpower Survey of the "lourism Industry by the Ministry of Iourism and the International Labour Organization.

can see from Exhibit 5, primary school and high school graduates form most of the lodging and restaurant personnel, while travel agencies have more high school and university graduates on their staffs. A graduate of a primary education program can attend a vocational high school of tourism where concentrated practical training is combined with theoretical knowledge. The Ministry of Tourism also contributes to tourism education by owning and operating 12 TUREM schools ("TUREM" stands for "Tourism Education Center"). These schools-which are also operating, three-star hotels-_educate and train almost 1,000 young people each year.

In addition to tourism educational programs run by Turkish universities, educationaI programs from the American Hotel \& Motel Association of the United States and the City \& Guilds organization from the United Kingdom are also available for many young people seeking entry-level positions with hotels, airlines, and travel agencies. Turkish hotel companies such as Bilkent Holding Company and Eresin Corporation also offer educational services to their employees.

\section{Cultural Factors}

As mentioned earlier; most Turks are Muslim and follow the rules of Islam. This affects the working relationship between Turkish citizens and the international companies they work for. For example, most of the Turkish people would like to visit mosques at noon on Friday - the holy day of the week-to pray. As a result, many companies have built their own masjid-a small temple- - on their premises for the convenience of their employees. The thinking of these companies is that it is better from an efficiency standpoint to provide a place for employees to pray at work than to have them leave the premises every Friday to go to an off-site temple.

Today, approximately 18 percent of women in Turkey wear head scarves as a proof of their Islamic belief and never take them off, at home or at work. This creates a problem in some situations, and many hospitality companies avoid employing women from this segment of society. 
There are two major religious holidays on the Islamic calendar each year: Ramadin and the Greater Bairam. Ramadan is the ninth month of the Muslim calendar, cluring which Muslims observe the Fast of Ramadan; throughout the month they fast during the day and in the evening eat small meals and visit with friends and family. It is a time of worship and contemplation, a time to strengthen family and community ties. The Greater Bairam is a feast that commemorates Abraham's sacrifice of Isaac. Most Turkish companies are closed during these holidays; however, hotels and restaurants are an exception, due to the nature of their businesses.

Islam bans the consumption of pork and wine. Pork has never been part of any dishes in Turkish cuisine, and pig-breeding has never been carried out by Turks. You should never suggest pork to a Turk. However, Turks do consume wine, which is in keeping with the history of their mainland, Anatolia, where wine was made for the first time in the world, at the time of the Hattian culture during the Bronze Age and during the succeeding Hittite Empire.

Tasty food of good quality is an important part of the Turkish culture. A decent breakfast with tea, a hearty lunch, afternoon tea or coffee time, and a proper dinner are all part of daily work life. At all Turkish hotels, resorts, and holiday villages, half-hour breakfast, lunch, and dinner breaks are customary for employees, with 15 minutes for tea time in the afternoon, and all of the food and beverages employees consume are provided free of charge by their employers. This adds up to an appreciable expense, considering that a mid-size hotel, for example, might have 50 to 100 employees.

Turks are creative, dedicated, hard workers and firm believers in group solidarity. Turks expect to be individually appreciated but motivated as part of a group. The group will recognize the authority of its supervisor if the person in charge is older than the group members he oversees, has more work experience, or is better educated than the employees in the group. While the performance of employees working for the government is typically low, employees in the bettermanaged private sector reach higher efficiency rates.

One should never question the nationalistic feelings of Turks; they are aggressively proud of their country. Also, the act of marriage is regarded as highly sacred by Turkish society.

As part of their custom, Turks are keen to help out people and are well known for the hospitality they show visitors to their homes. The hospitality of the Turkish people is also displayed at the companies where they work, contributing to the quality of services rendered. In the last few years, Turkish companies such as Kof and Sabanci Holdings have won world wide quality awards.

\section{Recruitment and Selection Practices}

The tourism and hospitality industries are people-intensive and encompass a wide range of services. Therefore, they employ labor from a diverse spread of occupations. The basic recruiting principle, of course, is to select the right person for the right job. Recruitment has long been considered one of the major human resource issues in Turkey, because of the nepotism that is prevalent throughout the country.

Although the National Recruitment Agency for Workers is the official source for getting a job in Turkey, it is not preferred by most unemployed citizens, due to 
its low placement rate. But it may begin receiving more attention from the public because of the introduction of the new social security law passed by the National Assembly on August 24, 1999, granting unemployed citizens the right to receive unemployment pay, backed by the unemployment insurance guarantee-both of which involve the agency.

Currently, the tourism and hospitality industries depend on teenagers to fill most front-line positions. Vocational high schools of tourism, vocational schools of tourism, and tourism management schools at the universities are the major employee sources for the tourism industry in Turkey. Although Law No. 3308 dictates that employers must pay three-quarters of the minimum wage to interns coming from vocational tourism high schools, there is no equivalent law to protect the rights of university students who seek to complete their student internships with a tourism or hospitality company. Therefore, companies can and do employ university interns without paying them, usually for three or four months during the peak tourist season. In most hotel companies, 20 percent of the staff is made up of interns, excluding the banquet department's part-time, on-call staff.

Graduates of Turkey's hospitality programs, as well as graduates from other disciplines (finance, accounting, humanities, and so on) who try to enter the tourism and hospitality job market, find it difficult to be hired on the merits of their education; they are often hired on the basis of who they know. Even international hotel companies that, in their own countries, readily hire college graduates on their own merits do not do so in Turkey; they too follow local customs, which means that applicants with relatives or friends within a company's current work force or who are backed by influential people get preferred over deserving applicants with no such support. This raises an ethical issue for the international hospitality companies. Favoritism in hiring damages the public faith in the fairness of these companies.

Another source of labor for hospitality companies in Turkey is experienced employees currently working in the tourism field. This is the most expensive way to recruit employees, and is only done when a company wants to hire an employee away from a competitor or when it has no other option.

An alternative source of labor is experienced employees who have worked in other service sectors or in other, non-tourist-related industries. When these people are hired over graduates of university tour ism or management programs, it causes university graduates to lose their confidence and the public to wonder about the value of a university diploma.

Non-traditional sources of labor, including senior citizens and people with disabilities, are also available for employment. However, few senior citizens look for a job, due to the social and cultural mores of Turks. Labor Law No. 1475, Statute 18 , Article 4, asks all employers employing more than 50 full-time employees to have at least two percent of their staffs made up of disabled people.

As mentioned earlier, most Turkish people try to get a job with the help of their relatives, which leads to nepotism. Companies also hire new personnel on the recommendations of their current staff. Turkish companies hardly ever put ads in newspapers or in human resource magazines. The new strategy is to share information on the human resource Web sites in Turkey. 


\section{Training and Development Practices}

The amount of training employees receive varies from company to company, depending on the quality of the company, the company's financial restrictions, and top management's philosophies. Large international companies and some midsize hotel properties carry out good employee training programs. These programs might be provided by the employers themselves, by Turkish universities, or by national or international consulting firms. Turkey's Ministry of Tourism continues to work with the International Labor Organization to create written materialssuch as job descriptions, job specifications, and detailed, step-by-step how-to manuals - for entry-level positions in hotels, restaurants, and travel agencies.

Training helps employees improve their ability to provide guest service; however, human resource departments must always consider if the training investment generates a return in terms of increased profits for the company. In properties with high turnover rates, training has been targeted as a way to decrease turnover, but training can still be a money-losing activity if trained employees quickly leave their jobs for better offers at competing properties.

Unions have a particular interest in training programs because these programs allow their members to attain better positions and achieve a measure of job security. Unions provide union training halls on work premises to provide employees with job-related training and training on general subject areas.

\section{Performance Evaluation Practices}

Employees are evaluated periodically within the scope of the training programs developed and directed by the human resource departments of hospitality companies. Scientific evaluation criteria have been adopted by most of the leading hospitality organizations. Employee performance evaluation methods vary from company to company and include the rating-scale method, peer-appraisal method, self-appraisal method, and appraisal-by-subordinates method. One of the best indicators of employee performance at resort properties is believed to be the employee's contribution to encouraging guests to stay longer this year or return next year.

Many managers in small- and mid-size properties depend on their intuition when evaluating employees, which can leave employees faced with unfair performance evaluations. Most of the criteria these bosses use are subjective; they do not rely on any scientifically approved evaluation method. When business is good, these bosses claim the credit; when business is down, they blame their employees.

\section{Working Women in Turkey}

The number of women who own or manage large hotels in Turkey-five-star properties and the like-is very low. However, a much higher number of women own or manage tra vel agencies (see Exhibit 6). In fact, Turkish women working in the tourism and hospitality industries have made substantial progress over the last 15 years. However, research shows that management jobs in Turkey are still dominated by men; Turkish organizations still prefer to hire or promote men into managerial and administrative positions. ${ }^{3}$ 
Exhibit 6 Percentage of Female Personnel at Each Level for Accommodation, Restaurants, and Travel Agencies

\begin{tabular}{|lccc|}
\hline Level & Accommodation & Restaurants & $\begin{array}{c}\text { Travel } \\
\text { Agencies }\end{array}$ \\
Top/General Management & $9 \%$ & $8 \%$ & $17 \%$ \\
Managerial & $24 \%$ & $9 \%$ & $43 \%$ \\
Supervisor & $16 \%$ & $4 \%$ & $42 \%$ \\
Broad-Skill Worker & $15 \%$ & $4 \%$ & $53 \%$ \\
Skilled Worker & $34 \%$ & $11 \%$ & $27 \%$ \\
Limited-Skill Worker & $5 \%$ & $13 \%$ & $23 \%$ \\
\hline
\end{tabular}

Source: 1993 Manpower Survey of the Tourism Industry by the Ministry of Tourism and the International Labour Organization.

The number of working women in Turkey tends to increase faster than the working population as a whole, as more Turkish women receive vocational education and have more opportunities to work. However, this increase has not resulted in a parallel increase in the number of female managers in the workplace. ${ }^{4}$ There are several potential reasons for this.

First, occupationalists argue that gender inequalities in management selection stem from the gender composition of jobs, in the sense that some lower-level jobs with limited opportunities for promotion, like teaching and secretarial work, are supposed to be more suitable for female personnel.

Another reason is the socialization of women, which leads many women to not aspire to high managerial positions and to be drawn to jobs traditionally staffed by women, such as nursing. Such socialization may lead working women to accept or prefer non-management jobs or jobs at low managerial levels, either because they feel less competent than men or because they lack motivation or fear success.

Last but certainly not least, family considerations and responsibilities tend to keep women from achieving high positions in the workplace. Factors such as raising children and a lack of mobility (women stay home to raise their children, and fewer women than men own cars or have access to cars) seem to be important reasons for women's absence from senior management positions.

\section{The Expatriate Manager}

Encounters of Turks with expatriate managers go back to the development of the Bosphonis Hotel, now called the Pera Palas, built in 1892 in Istanbul during the Ottoman Empire years by the Compagnie Internationale des Wagon-Lits, the owner of the famous Orient Express train. After two world wars and their aftermath interrupted international ventures, another early introduction of expatriate managers occurred in 1955, when the Hilton Hotel Company won a bid to operate 
a hotel in Istanbul that the Turkish government built with Hilton's assistinnce-this hotel was Hilton's third overseas investment and only its second hotel management venture in Europe, after the Hilton Castillana in Madrid, Spain.

Expatriate managers work in Turk-owned companies as well as international companies. In this section we will take a brief look at some of the problems and opportunities expatriate managers face in Turkey.

\section{In Turkish Companies}

While there are a number of expatriate managers working for international tourism companies in Turkey, few work for tourism companies owned by Turks. Those few expatriate managers who do work for Turk-owned hospitality companies are well known, experienced managers who formerly worked for international hospitality chains in Turkey and have proven track records in Turkey. These managers are very familiar with the Turkish culture and know how to comport themselves in Turkish society. Moreover, they are able to reach out to new, foreign market segments for the benefit of the Turkish companies they work for. Turkish hospitality companies looking to hire expatriate managers typically have good reputations in the international-trade arena and sound relationships with and high respect from foreign businessmen.

\section{In international Companies}

Four Seasons, Hyatt, Renaissance, Hilton International, Conrad, Ceasar's, Holiday Inn, Sheraton, Swissotel, Kempinski, Intercontinental, Mercure, Ramada, SAS, Corinthia, Club Med, Sol Group, Robinson, lberotel, and Aldiana are the major international hotel companies currently operating hotels, resorts, and holiday villages in Turkey, mostly in such major metropolitan cities as İstanbul, Ankara, İzmir, Adana, and Mersin, and at resort destinations on the Aegean and Mediterranean coasts. Most of these companies prefer to have expatriate managers in the top management positions of their Turkish operations. Notable exceptions are the Holiday Inn company and the Mersin Hilton SA Hotel in Mersin.

The internationalization of production affects the human resource function in a number of ways and makes management more difficult. ${ }^{5}$ First, the management task becomes increasingly complex; for example, the business becomes involved in international compensation, taxation, and insurance issues. Second, managers must cope with expatriate staff members who have (or whose families have) more than the ordinary financial, health, or schooling difficulties in their new country; the scope of these types of problems typically is much less in companies staffed entirely by natives.

The current international business environment is increasing the incentive for international companies to transfer managers to operations outside their native countries for reasons of personnel and organizational development. With the growth of international mergers and acquisitions, joint ventures, and alliances, the value of having international management teams able to operate across a range of cultures is considerable indeed.

The growing importance of international experience means that companies are paying considerable attention to expatriate-manager selection and are looking 
for ways to minimize the problem of expatriate-manager failure. There are three main reasons for expatriate-manager failure: ${ }^{6}$

1. Inappropriate selection of expatriate managers. They were selected simply because they were successful in the company's domestic market, so it was assumed they would be successful overseas.

2. Inadequate preparation and training. They were not given the proper training they would need to be successful in a new country.

3. Stress associated with expatriation. Their job performance suffered because of the stress associated with learning about a new culture and working in a dif ferent work environment- - even from the stress associated with worries about possible repatriation problems when the managers were eventually sent back home.

Because of these and other reasons, some international companies think that the best strategy is to recruit and develop home-country managers for their international operations. This is hard to do, however, because the international companies usually have a poor knowledge of the labor markets and educational standards outside the country from which they are based. Cultural and linguistic problems can also crop up when selecting home-country managers for foreign operations, and international companies may use, unknowingly, inappropriate recruitment methods. ${ }^{7}$ However, these problems are minimized in Turkey, because it has a large number of properly educated and experienced staff members ready to take over responsible positions with international companies.

\section{Corporate Cultures}

\section{Turkish Corporate Cultures}

The administrative structures of Turkish tourism and hospitality companies are very similar to international companies' structures, with one major exception: the general manager's ability to manage the company. In Turkey, most of the single owners or the families that possess a majority of a company's shares claim the right to have the final word on all company issues, without considering the advice of their companies' top management professionals. Top managers of Turkish companies are not given by their companies' boards of trustees the responsibility and authority commensurate with the positions they hold. Many general managers in Turk-owned hotels cannot even sign a check of a few thousand dollars on their own. Certainly, this discourages these managers and lowers the job satisfaction they can achieve from working for such a company.

Professional managers usually resign as soon as they can from companies run by,such independent owners. These owners then look for other top-level managers and will hire one who might not be as qualified as the previous manager but who is willing to carry out the owners' bidding without question.

This approach prevents the implementation of contemporary, scientific management methods to overcome company problems. The unsuccessful promotional efforts by Turk-owned hotels, resorts, and holiday villages on the Aegean and 
Mediterranean coasts point to the fact that the Turkish owners of these properties cannot get together to support their common product through their local trade association, or band together to lobby for higher tour-package prices from the world's largest tour operators (TUI, NUR, Thompson, DER, etc.). In the absence of professional managers on their staffs (because the owners are overbearing), hotels, resorts, and holiday villages in the newest and most beautiful destinations on Turkey's Mediterranean coast stay poorly promoted and do not receive their fair share of the market.

\section{International Corporate Cultures}

The advantage international hospitality companies have in Turkey over Turkish companies is that they have better organizational structures and give their top managers the responsibility and authority they need to oversee daily operations. The expatriate managers of international companies bring with them the required education and training. At the same time, ideally, these managers must have the ability to understand and work in the local culture. The successful expatriate managers of international companies can help develop middle managers recruited from the local labor force.

International companies have also made mistakes from time to time, such as transferring to Turkey human resource directors who do not speak Turkish and have little or no knowledge of the legal framework or the personnel issues in Turkey. Without understanding Turkish rules and regulations, these expatriate human resource directors are forced to call the human resource directors of competing hotels, often English-speaking Turks, every time they have to make a decision. This helps explain why Turkish natives within the industry are puzzled by such appointments.

\section{Trends in the Near Future}

The expansion of multinational corporations is a major-perhaps the major-phenomenon of the international economy today. Tourism and hospitality companies play a big part in this expansion. International hotel chains penetrate new markets in China, Central Asia, and Eastern Europe. Airlines fly to new and more remote destinations, and tour packages are put together even for such f a roff places as the North Pole and the lonely steppes of Mongolia. The world is getting smaller and cultures are coming into closer contact with each other.

More foreign investments are expected to enter the Turkish economy. As the number of international companies in Turkey grows, more expatriate managers are expected to come to Turkey to take charge of these companies, and more workers from forcign countries are expected to come to Turkey. International companies, bringing to Turkey more expatriate staff members, should help improve the working standards of the Turkish work force. Turkish businesses and personnel will also benefit from the technological breakthroughs and organizational innovations of these international companies. At the same time, the expatriate staffs of these international companies will learn about Turkish culture. 
For this new wave of expatriate managers, there will be no clear-cut guidelines. Success will come through the adaptation and integration of prior experience with local realities. These managers will develop new management approaches based on local advice and their best judgment.

\section{Endnotes}

1. "Turkey," MSN Encarta Learning Zone (2000), available at http:/ /encarta.msn.com/find/ Concise.asp?ti=05D7D000.

2. State Institute of Statistics (2000). "Economic and Financial Data for Turkey" (on-line) Available: http:/ /www.die.gov.tr/TURCAT/turcat.html\#Population.

3. Terıy C. Blum, Dail L. Fields, and Jodi S. Goodman, "Organizational-Level Determinants of Women in Management," Academy of Manngement Journal, 37 (2): 241-268.

4. Meryem Akoğlan and Öznur Yüksel, "Managerial Behavior and Effectiveness: Perceptions of Female Managers in the Hospitality Industry;" Awntulia, 9, no. 1 (Summer 1998).

5. P. J. Dowling, "International and Domestic Personnel/Human Resource Management: Similarities and Differences," in R. S. Shuler et al, eds., Readings in Persunnet and Human Resource Management (St. Paul, Minn.: West Publishing, 1988), 456-462; and P. Enderwick, "International Human Resource Management," in P. J. Buckley and M. Brooke, eds., Internationnl Business Studies: An Overviezv (Oxford: Basil Blackwell, 1992), 523-539.

6. W. Holmes and F. K. Piker, "Expatriate Failure: Prevention Rather than Cure," Personnel Manngement, 12 (1980), 30-33; and M. Mendenhall and G. Oddou, "The Dimensions of Expatriate Acculturation: A Review," Acndemy of Manngement Revicrv, 10 (1985), 34-37.

7. H. Scullion, "Attracting Management Globetrotters," Persumnel Managenent, 24 (1992), 28-32.

\section{Coy Terms}

DER-The second largest German tour operator.

holiday village-A type of hotel, usually located at a resort destination, that offers simple accommodations but emphasizes food and beverage service, recreational facilities, and entertainment activities.

mas jid-A very small mosque, in terms of available area to pray, with no minaret.

mixed-economy system-A system where public and private sectors co-exist in the country's economic activities and ownership of resources. Some business and economic decisions are made by individual businesspeople and private-sector firms, some by government.

NUR_-One of the largest and most influential German tour operators.

TUREM schools-"TUREM" stands for Tourism Education Centers. These are schools, which are also operating, threestar hotels, owned and managed by the Turkish Ministry of Tourism, where students study theoretical hospitality knowledge and practice job skills on the spot. 
TUI-The top Cerman tour operator, created by the unification of several travel agencies.

Thompson-One of the largest British tour operators.

\section{? Discussion Questions}

1. What sorts of problems may Turkey be faced with in the near future, as a result of having 55.6 percent of its population under the age of 25 ?

2. What are the three social security systems for Turkey's working citizens?

3. Why are hotels, resorts, and holiday villages on the Aegean and Mediterranean coasts of Turkey obliged to pay low salaries to their employees?

4. What is Ramadan and the Greater Bairam?

5. What are the major sources of labor in the Turkish tourism and hospitality industry?

6. What are three major reasons for expatriate-manager failure?

\section{Internet Sites}

For more information, visit the following Internet sites. Remember that Internet addresses can change without notice.

Turkey: MSN Encarta Learning Zone http:/ / encarta.msn.com/ find/

Concise.asp?ti=05D7D000)

Republic of Turkey, Prime Ministry, State Institute of Statistics (SIS) http://ww die.gov.tr/ENGLISH/

Republic of "Turkey Website

http:/ / www.turkey.org/start.html

\section{OCase Study}

\section{A Tale of Two Dreams}

Jasmin and Bora are two university seniors studying at a highly renowned Turkish university's school of tourism and hotel management. During the fall semester of their senior year, both must complete an internship program, working 15 weeks in a hotel on a full-time basis. With the help of the school's placement office, both have landed an internship with different leading international hotels. Jasmin has been asked to work in Hotel A's highly acclaimed fitness center, while Bora has been assigne d to Hotel B's public relations department.

They both work hard at their jobs, to prove to their hotels' managers that they are good students who deserve to be hired upon their graduations. During their internships, they know that they won't be paid, as is the custom in Turkey, because there is no law that protects the employment rights of university interns. They consider their unpaid internships as opportunities to earn job offers from their hotels for jobs after graduation. 